\title{
TOURISM EVOLUTION IN RURAL SOUTH AFRICA: FROM NATIVE RESERVE TO APARTHEID BANTUSTANS c 1920-1994
}

\author{
Christian M. ROGERSON* \\ School of Tourism \& Hospitality, College of Business and Economics, \\ University of Johannesburg, Bunting Road, Johannesburg, South Africa, e-mail: chrismr@uj.ac.za
}

Citation: Rogerson, C.M. (2022). TOURISM EVOLUTION IN RURAL SOUTH AFRICA: FROM NATIVE RESERVE TO
APARTHEID BANTUSTANS c c 1920-1994. GeoJournal of Tourism and Geosites, $40(1), \quad 120-128$.
https://doi.org/10.30892/gtg.40114-810

\begin{abstract}
Historical research is valuable for understanding the evolutionary pathways of tourism destinations. The aim is to contribute to the historical tourism scholarship of rural destinations in the Global South. The focus is the development pathways of rural tourism in specific areas of South Africa, namely the rural (former) Homelands or Bantustans that were created by apartheid planning. The study uses an archival approach with material sourced from a range of historical documentary sources. The historical specificities of these rural spaces catalysed the appearance of particular forms of rural tourism. The analysis unfolds through three sections of material. First, the earliest period for the development of tourism in the 'Native Reserves' is chronicled. The second section reviews the apartheid project for the making of the Bantustans. Third, the tourism developments occurring in these rural spaces are examined for the apartheid period from 1948 to the early 1990s focussing especially on the phenomenon of casino tourism.
\end{abstract}

Key words: rural tourism, archival research, native reserves, Bantustans, South Africa

\section{INTRODUCTION}

A quarter of a century ago Britain's leading historian of tourism, John K. Walton, implored scholars to 'take the history of tourism seriously' and address its limited research development (Walton, 1997). Several influential works subsequently authored by Walton $(2005,2009 a, 2009 b, 2009$ c, 2011) provide a compelling case for further correcting the 'presentmindedness' of mainstream tourism scholarship. Arguably, tourism history is critical for interpreting the processes of the evolution of destinations as pinpointed by Hanpachern and Chatkaewnapanon (2013). Further, an "insightful understanding of current patterns of tourism growth cannot be completely comprehended without examining how tourism systems have been established and have evolved over time" (Bui, 2021: 1). According to Walton (2009b:115) "all tourism research needs a sense of historical awareness" as "the present cannot be understood without reference to what has gone before". Another recent call for building historical tourism scholarship was made by Saarinen et al. (2017: 311) who urged "the extended application of historical perspectives in order to inform contemporary debates and practices".

The aim in this article is to contribute to the historical tourism scholarship of rural destinations in the Global South. The focus is the development pathways of rural tourism in specific areas of South Africa, namely the rural (former) Homelands or Bantustans that were forged under apartheid planning (Phillips, 2017). The analysis starts in the 1920s when tourism began to evolve in the country and concludes in the years of late apartheid and democratic change in 1994 which consigned the Bantustans to the proverbial dustbin of history. Although the majority of literature concerning tourism in South Africa centres on contemporary issues and debates, an observable trend in the country's tourism scholarship is the emergence of several research investigations which excavate tourism's past and tourism history. Arguably, an understanding and learning from the past is highly relevant in the uncertain times of the COVID-19 environment (Rogerson and Baum, 2020; Rogerson and Rogerson, 2021a). The appearance and strengthening of an historical tradition in South African tourism scholarship is distinctive in tourism literature about the Global South most especially as it furnishes fresh insight into processes of tourism destination change (Rogerson and Rogerson, 2021a; Saarinen and Rogerson, 2021).

The existing historical writings have been produced both by tourist historians (eg. Carruthers, 1989, 1995; Grundlingh, 2006; Saunders and Barben, 2007; Bickford-Smith, 2009; Dlamini, 2020; Pirie, 2022) and increasingly by tourism geographers of South Africa (Rogerson and Visser, 2020). Historical tourism studies in South Africa have been undertaken at various scales of investigation - national, regional, and local - and for both urban and rural areas. In terms of tourism in urban settings historical contributions include studies investigating the making of urban tourism in the country's major cities of Johannesburg (Rogerson and Rogerson, 2019, 2021b), Cape Town (Bickford-Smith, 2009), and Pretoria (Rogerson and Rogerson, 2022a) as well as small town resorts such as Hermanus (Rogerson and Rogerson, 2020a). The development of the heritage tourism base of Mahikeng also has come under scrutiny (Drummond et al., 2021). Thematic examinations have been undertaken concerning the changing complexion of the accommodation services sector at different geographical scales (Rogerson, 2011; Rogerson, 2013, 2018; Rogerson and Rogerson, 2018; Rogerson, 2019, 2020; Rogerson and Rogerson, 2022b) and including the activities of pioneer African entrepreneurs in the hotel trade (Sixaba and Rogerson,

\footnotetext{
* Corresponding author
} 
2019). Other urban-focused research explores the chequered development of early health tourism (Rogerson and Rogerson, 2021c), the evolution of caravanning as a mundane form of urban tourism (Rogerson and Rogerson, 2021d) and, the growth of business and conference tourism in South Africa (Rogerson, 2019). The impress of apartheid legislation on tourism trajectories including the struggles against the production of racialized tourism spaces represent a further group of research studies (Rogerson, 2017; Rogerson, 2020; Rogerson and Rogerson, 2020b). In rural areas the largest amount of work concentrates on the social history (Dlamini, 2020) and the establishment of various protected areas (Carruthers, 2011) and most especially of game reserves such as Kruger National Park (Carruthers, 1989, 1995; Brett, 2018). The formative years of mountaineering (Carruthers, 2013) as well as the evolutionary pathways of early rural tourism in South Africa also have been analysed (Rogerson and Rogerson, 2021e).

This study concerns the evolution of tourism in the apartheid-created rural Bantustans. It contributes an understanding of the distinctiveness of rural tourism in South Africa as an aspect of tourism change in the global South (Saarinen and Rogerson, 2021). The establishment of the Bantustans was once styled famously by the anti-apartheid activist Steve Biko (1987: 83) as "the greatest single fraud ever invented by white politicians". The analysis unfolds through three different sections of discussion. First, the earliest period for the development of tourism in the 'Native Reserves' is chronicled. The second section reviews the apartheid project of the making of the Bantustans. Third, the tourism developments taking place in these rural spaces are examined for the apartheid period from 1948 to the early 1990s including the phenomenon of casino tourism. In terms of methods the study applies an archival approach. At its core Mills and Mills (2018) observe that archival research involves the study of collections of documents - pamphlets, newspapers, annual reports, memoranda - to gain an understanding of historical phenomenon and processes. Archival repositories for this study include the Historical Papers Collections of the University of the Witwatersrand (Johannesburg), the collections at the National Library of South Africa (Cape Town depot), and, the record of House of Assembly debates.

\section{INTERNATIONAL TOURISTS IN SEARCH OF THE PRIMITIVE}

According to Grundlingh (2006: 111) deeply embedded in the historical marketing of South Africa as a tourist destination was "the juxtaposition of the 'primitive' and the 'modern"'. Rassool and Witz (1996) point to the long history of tourists being attracted to visit South Africa because of opportunities to view 'native life in its tribal state' as manifested in 'authentic African settings'. During the 1920s, a time of the beginnings of marketing for international tourist visits to South Africa, it was recognised that "with natural beauty, a comfortable climate and, not the least important, an exotic, indigenous non-western people South Africa was a natural for the tourist trade" (Wolf, 1991: 101). As early as the 1930s in parliamentary debates taking place about tourism development in South Africa there was awareness that alongside the game reserves, natural scenery and the gold mines a leading attraction of South Africa was “our native life" (House of Assembly Debates, 19 February 1937 Col. 2024). In 1936 a major national investigation of the country's tourism industry highlighted "the bounteous gifts South Africa has to offer in the way of varied scenic beauty, of her fauna and flora, and of her native life in all its attractive picturesqueness" (Norval, 1936: 128).

A vital role in the early development of tourism in South Africa was assumed by the expansion of the railways and the promotional advertising from 1910 that was produced by the South African Railways and Harbours (SAR \& H) organisation (van Eeden, 2011). The advertising of South Africa emphasized the country's untouched and 'primitive' attractions but at the same time stressed that these could be experienced all in perfect comfort. Publicity material produced by SAR \& $\mathrm{H}$ directed at the international tourist proclaimed as follows:

"Gone are the days when Southern Africa was looked on as a land of unknown dangers, primitive in its make-up and savage in its composition. Nowadays the ultra-modern and the primitive go hand in hand, and constitute perhaps the country's most potent appeal to the citizens of the overcrowded older countries. Fascinating natural wonders, curious mysteries of past ages, kraals and settings of a coloursome native life, and the vast solitudes of the veld and rugged mountain areas can all be visited in comfort" (South African Railways and Harbours, 1934: 2).

Promoting the imaginary of 'Savage South Africa' had often formed part of the human showcases at exhibitions, theatres and galleries in Europe and America during the $19^{\text {th }}$ and early 20 $0^{\text {th }}$ centuries (Rassool and Witz, 1996: 359). Following accusations of racism these 'savage' human showcases gradually were phased out and mostly had disappeared by the 1930s with the consequence that in order to observe 'native life' Europeans and Americans "now had to come to Africa to see primitiveness on display" (Rassool and Witz, 1996: 359). Wolf (1991: 107) argued that in the 1920s and 1930s that "the African population was high on the priority list of what potential tourists from America wanted to see". The message of viewing the 'primitive' with comfort was conveyed to potential American visitors in an advertisement posted by the South African Government Bureau in New York and which appeared in a travel magazine in 1929:

"South Africa is one of the most modern and progressive sections of the world...luxurious hotels and railroads, delightful golf and yachting clubs, superb motor roads, and all the comforts and conveniences of modern civilization... But there is also the immensely picturesque native side of South Africa so alluring to the tourist...the quaint Kraal life... wild war dances... weird, age-old tribal customs... the dignified Zulu chief and his retinue of dusky wives...stalwart warriors with their spears, shields and knobkerries... the primitive musical instruments... the women's fantastic headdresses... the superstitious mummery of the witch doctor (Travel, October 1929: 31 cited in Wolf, 1991: 107)". The two areas of South Africa where 'native life' was offered as an attraction to tourists were the rural spaces of Zululand and the Transkei.

The history of tourism in Africa has an unfortunate record of exploitative and demeaning portrayals and of dehumanizing people by treating them as objects (Pirie, 2022). This is clearly exemplified in SAR \& H advertising and the portrayal of 'Native life' from the 1920s and continuing into the late 1940s. In one 1926 pamphlet it was stated: "Although 
the native in his raw state may be seen in many parts of South Africa, it is in Zululand, more particularly, that one meets him at his best. Here he is to be seen in his old-time simplicity. He is in his true environment, amidst the rural and peaceful surroundings of his forefathers, where the savage Chaka - the Black Napoleon - lies buried but not forgotten, though a century has passed" (South African Railways and Harbours, 1926: 9). In a dedicated SAR \& H publication produced in 1936 'native life' was described as both of "absorbing interest to the dilettante" and contributing 'novel allure' to make South Africa "a veritable tourist paradise" (Uys, 1936: 5). The pamphlet highlighted various aspects of 'Native life' that might attract visitors, including traditional marriage ceremonies, crafts such as mat-making and the production of ornamental weapons, musical instruments, superstitions and witchcraft. Notably, the operations of 'witchdoctors' were given much attention with the recommendation that "no visitor to South Africa should miss" (Uys, 1936: 27).

Much prominence was accorded to the presentation of pictures of Zulu chiefs and 'warriors' as welcoming of visitors (Figure 1). This imaging of Zululand continued into the late 1930s. In a 1937 Railways publication Zululand was described for potential international visitors as "a huge intriguing native area" where "the natives in their primitive state provide thoroughly interesting studies" (Carlyle-Gall, 1937: 18). Visitors were advised this "is essentially a rather primitive corner of Africa" where "on the verdant hillsides of the interior, Zulu herd boys watch their charges, while bead-bedecked women hoe the fields and the lordly menfolk gaze over the rolling landscape and talk of valorous days that are no more" (CarlyleGall, 1937: 69). Similarly, in 1939 the region was styled as enjoying a "wealth of native life" with "stalwart warriors" (South African Railways and Harbours, 1939: 2) and further reiterated that the "Zulus are a most fascinating people" (South African Railways and Harbours, 1939: 19). In a description appended to one photograph of a Zulu 'warrior-chief' it

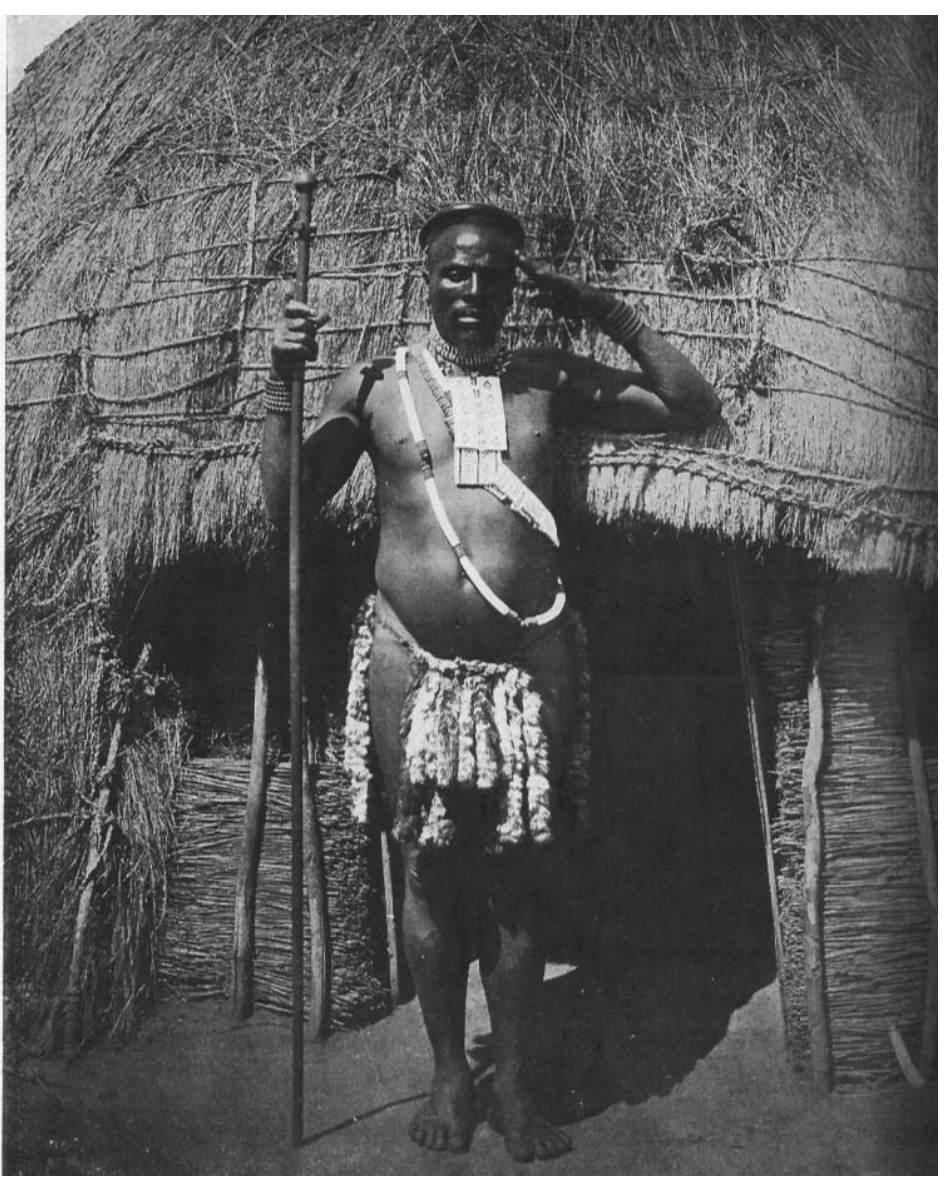

Figure 1. Profiling of 'Native Life' in South African Railways Advertising in the 1930s (Source: South African Railways and Harbours, 1939: 1) was stated: "save for the colour of the skin and the texture of the hair, this Zulu warrior, by his seminudity and the symmetry of his limbs, might well be taken for a bronze statue of a Roman gladiator come down from its pedestal" (Uys, 1936: 11).

The territory of the Transkei began to open up for tourism with the rail linkage to Umtata (established for migrant workers to the gold mines) and importantly also in the 1930s because of improvement in roads. Publicity material from the South African Railways in 1937 stylized this area as "a strange primeval land" with "picturesque Bantu life" (Carlyle-Gall, 1937: 75). As in Zululand the marketing of this region focussed mainly around 'the primitive' and on the attractions of 'Native life'. This is shown in the following descriptor:

"It is the unique privilege of the visitor to South Africa to be able, as it were, to step from the pulsating twentieth-century scene into a vastly different world - the ancestral domain of the native. And in the Transkeian Territories human society in its very beginning is to be seen in the weirdlyromantic native reserves" (Carlyle-Gall, 1937: 79).

Assurances were provided, however, that "present-day urban amenities are much in evidence", "accommodation is, in every respect, entirely satisfactory, the hotels being up to date" and, whilst tourists enabled to view the magnetic attractions of the Transkei, they are "at the same time not deprived of the amenities of modern life" (Carlyle-Gall, 1937: 77). South African Railways publicity material about the Transkei and Zululand as 'The Real Africa' continued into the early apartheid period (South African Railways Tourist Office 1949). Native life "in the raw" was promised as the appeal of these areas offering "singularly rich fields for the searcher after the primitive" (South African Railways Tourist Office, 1949: 1). As described for the 'Native territories' of Transkei and Zululand: "Here the Native goes about his daily round in much the same manner as he did before the coming of the white man. Tribal customs are observed with all their colourful solemnity; periodical dances are staged with vigorous enthusiasm; and even in respect of simple domestic duties the ways of the Native are full of quaintness and interest to folk accustomed from infancy to European ideas" (South African Railways Tourist Office, 1949: 1). In depicting the populations of the 'Native territories' as 'exotic', 'traditional' and 'primitive' with landscapes that are 'wild' and 'untamed' tourist representations of these areas were positioned as the polar opposite of the 'modern', 'civilised' tourists and their normal vacationscape (Wildman, 2005). Through all its promotional activities for Transkei and Zululand in the 1930s and 1940s the SAR \& H took great care to emphasize the modern comforts of the country's railways and suitability for 'genteel leisure visitors', including women. 


\section{THE MAKING OF BANTUSTANS AND GOVERNMENT POLICY NEGLECT OF TOURISM}

The landmark 1948 electoral victory of the National Party launched a fresh chapter in terms of tourism development in the 'Native territories'. In particular it ushered in a period of policy indifference and neglect of tourism development as the state focussed on consolidating its power and began its apartheid project which embraced a critical focus on these spaces (Grundlingh, 2006). Arguably, the utilization of space by the apartheid state to segregate and control the African population "was deeply rooted in South Africa's colonial period (1652-1948)" (King and McCusker, 2007: 6). According to King (2006: 81) the electoral victory of the National Party in 1948 "resulted in the emergence of apartheid policies that reinforced colonial systems of spatial segregation, control of movement and production, and empowerment of traditional governance systems". Issues around tourism were not under serious consideration until 1963 with the establishment of a Department of Tourism (Grundlingh, 2006). The implementation of the policy of 'Bantu Homelands' became a mainstay of apartheid planning (United Nations Centre Against Apartheid, 1970; Phillips, 2017). Beinart (2012) points out that homeland policy was implemented relatively slowly and unevenly during the apartheid years. This was achieved by initial consolidation of the 'native reserves' and subsequently providing the imagined territories with self-governance.

The Bantu Authorities Act of 1951 was the original piece of legislation that provided the legal foundation for the establishment of the Bantustans. The apartheid government created the homelands "on the basis of its definitions of peoplehood" which drew upon the work of government ethnologists and politically conservative anthropologists to form "the idea of peoplehood in terms of a discrete cultural, linguistic, and political identity" (Schutte, 2003: 474). In terms of the socio-economic development for the Homelands in 1950 the Government appointed a commission under the Chairmanship of Professor F.R. Tomlinson "charged with the task of devising a "comprehensive scheme for the rehabilitation of the Native Areas with a view to developing within them a social structure in keeping with the culture of the Native and based upon effective socio-economic planning"' (Hobart Houghton, 1957: 14). The Tomlinson Commission conducted a mammoth investigation into the question of social and economic planning in the Reserves with its results presented in 18 volumes and an abridged summary report published in 1955 (Union of South Africa, 1955). The policy findings were submitted to government in 1954. The core problem in the reserves was identified as the lack of non-agricultural wage opportunities. The Tomlinson report estimated that 50000 employment opportunities would have to be created each year for the following 25 years. Its central proposals mirrored those of previous studies in its advocacy of the need for a general reform of agriculture and the diversification of economic activities through the industrialisation of the Reserves and the bordering 'White' areas (Nieuwenhuysen, 1964).

The growth of industrial capacity was favoured as the potential basis for new job creation. The Tomlinson report stated that "a programme of industrial development will, therefore, occupy a central position in the general programme of development for the Bantu areas" (Union of South Africa, 1955: 131). Evans (2019) sees this recommendation as aligned to the growth of interest in broader colonial planning for rural industrial development at the period of the end of empire. In the late 1950s "the apartheid government shifted its focus to 'separate development' and emphasized that the homelands would eventually become independent from the South African state" (King, 2006: 82). Under the 1959 Promotion of Bantu Self-Government Act a number of ethnic territories were established with a system of local government. The most significant was the Transkei territory which was formalised in 1959 and became 'semiautonomous' and 'self-governing' in 1963 (United Nations Centre Against Apartheid, 1970). At the macro-scale Smith (2004) suggests that the Bantustan strategy was explicitly aimed at reducing the growth of African urbanisation and most especially in and around the economic heartland centred upon Johannesburg and Pretoria. The construction of the homelands was seen as central to a shift in the $1960 \mathrm{~s}$ of state policy towards 'high apartheid' and involved the classification of the African population into various ethnic categories that enabled the state to forcibly relocate urban and rural residents" (King, 2006: 81). Initially viewed as a source of cheap migratory labour it is argued that over time "the 'homelands' were decreasingly significant as suppliers of migrant labour, and increasingly important as repositories of surplus people" such as the unemployed and underemployed who were "corralled" into these areas (Beinart, 2012: 14).

As shown on Figure 2 the apartheid state demarcated ten ethnically-based Homelands. Lissoni and Ally (2018: 1) argue that the Bantustan project, albeit presented as a form of black self-determination, was "rejected by the liberation movement and its supporters as a political fraud: reservoirs of cheap African labour ruled by "puppet" governments, often consisting of illegitimately installed chiefs (and white civil servants from Pretoria), governed by tribal custom and coercive force". Notwithstanding assertions by the apartheid government that the homelands represented ideal units for separate development "the geographical organization of these spaces revealed their true intent to remove blacks from white areas and undermine the black population's capacity for political and economic empowerment" (King, 2006: 81-82). Behind the smokescreen of 'separate but equal' there was a reality of blatant racial oppression in the homeland system as apartheid sought to destroy African economic prospects and strip blacks of citizen rights in order to perpetuate white rule (Southall, 1982; Jensen and Zenker, 2015). The homelands represented "an economic ploy to ensure South African industry of a continuous supply of cheap black labour without paying any social price for it" (Schutte, 2003: 474).

Overall "very limited resources went to the homelands, critics maintained, rendering any semblance of economic autonomy ludicrous" (Jensen and Zenker, 2015: 941). Nevertheless, wasteful expenditure characterised the Homeland project with one of the most extreme being the extraordinary profligacy that South Africa attempted to build 10 new capital cities, one in each of the ethnic Homelands. As apartheid policies became more pronounced in the 1960s and 1970s the national government focussed attention on moving the Bantustans towards independence (King and McCusker, 2007; Phillips, 2017). The Bantu Homelands Constitution Act No. 21 of 1971 was the keystone legislation which gave South Africa the authority to grant independence to any of the Bantustans. Of the ten ethnic Bantustans only four - Transkei 
(1976), Bophuthatswana (1977), Venda (1979) and Ciskei (1981) - eventually become 'pseudo-states' by acceding to 'independence' under the programme of grand apartheid (Jones, 1999). This change of status from self-governing state to 'independence' provided, however, a changed institutional environment for tourism development to occur in these areas.

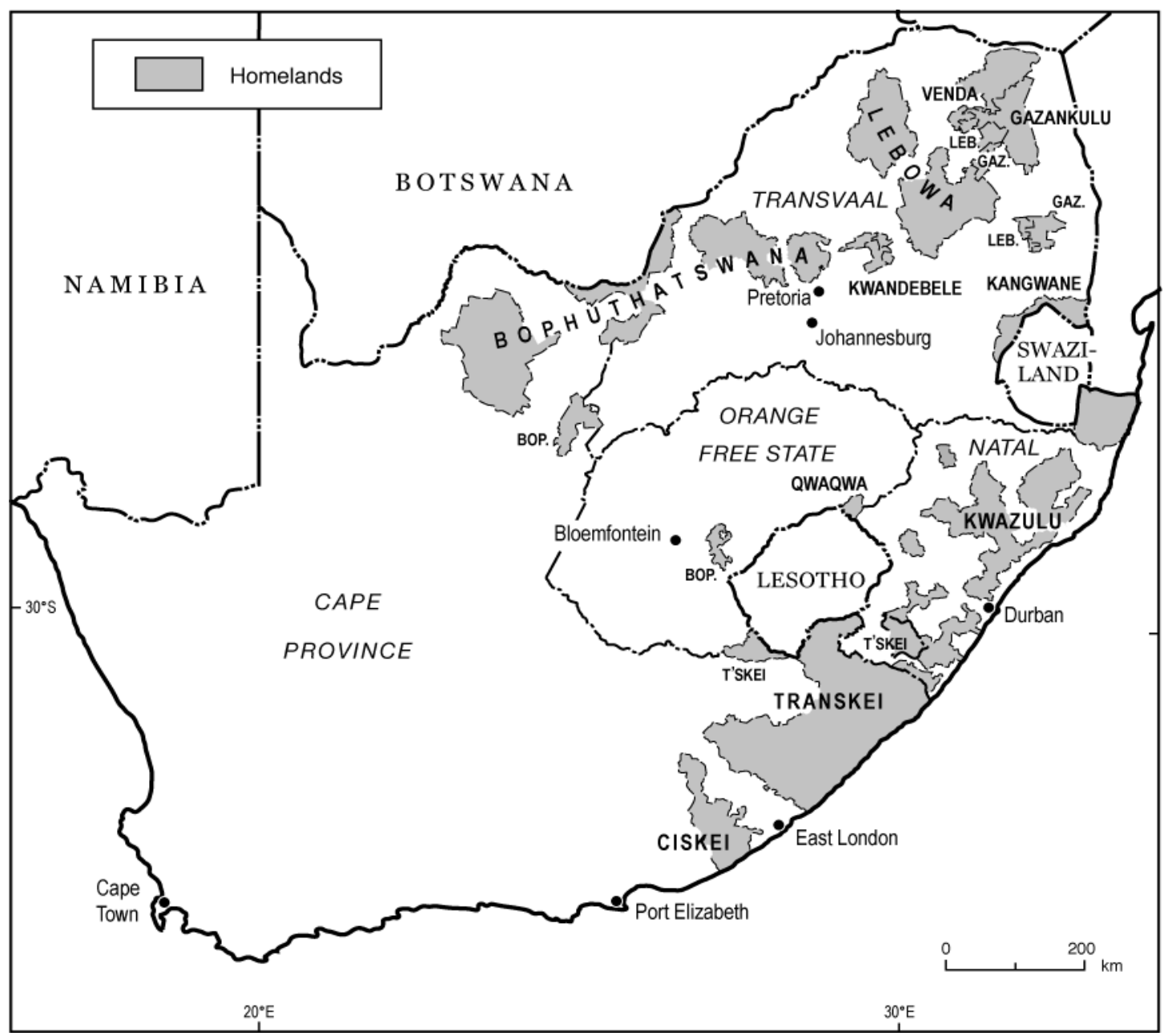

Figure.2. The Spaces of the Bantustans or Homelands of Apartheid South Africa (Source: Author)

\section{TOURISM IN THE HOMELANDS UNDER APARTHEID}

Given the lack of interest of the newly elected (1948) National Party government in tourism development as a whole, it is not surprising that tourism was not under consideration in the socio-economic planning report undertaken by the Tomlinson Commission (Union of South Africa, 1955). Pockets of tourism growth, however, did occur most notably at the Wild Coast area of Transkei which was a favoured destination for (white) domestic tourists from the 1940s. The Wild Coast was opened up for tourism by white cottage owners who confected the small seaside settlement of Coffee Bay with holiday cottages. By the 1960s Wildman (2005: 88) argues that Coffee Bay began to attract "a lot of domestic tourists" and in the early 1970s Coffee Bay even could be styled as "a flourishing holiday village" that was an increasing popular focus for the growing market of (white) domestic tourists under apartheid (Wildman, 2005: 96).

This area was exceptional for during the apartheid years mobilities and access to the Homelands often was challenging and restricted which constrained possibilities (especially) for rural tourism in villages. The message was stressed in parliament debates in the mid-1960s that international tourists coming to South Africa primarily were interested in wildlife "or else they come to see the Bantu" (House of Assembly Debates, 30 September 1966 Col. 3286). Rassool and Witz (1996: 360) highlight that visits by international tourists to the 'picturesque bantu-lands' were made difficult because "the roads and the accommodation in the 'native territories' were not adequately developed". In addition, permits were required from the Secretary for Bantu Administration to visit many rural areas with the public restricted to only the highways running through Homeland territories. Schutte (2003: 474) reflects that "to take a byroad was an offense that not only incurred a fine but also made the offender politically suspect". Indeed, those who did not adhere to government regulations were warned that they would be 'severely punished' (Rassool and Witz, 1996: 360). As a consequence, under apartheid legislation the public had "limited opportunities to observe indigenous 'traditional' culture due to restrictions on tourism in the homelands" (Schutte, 2003: 474). This said, it was stressed another limitation on international tourists in these areas was the fact that "most significantly many tourists were coming to the conclusion that in the 'native territories', the 'natives' were not native enough" (Rassool and Witz, 1996: 360). One example from Natal of the dwindling of 'native life' was the controlled tours to the Valley of a Thousand Hills, the so-termed 'House of the Zulu', where tourists expressed 
growing disappointment on finding that the juxtaposed to the traditional thatched huts that they came to view were walls of corrugated iron as a reflection of 'modern' housing. In Natal organised tours were reorganised such that they were no longer "of that character where the tourists are really allowed to see exactly what the life of a Native kraal is, in the manner that they used to do some years ago" (House of Assembly Debates, 30 September 1966 Col. 3286).

Policy development surrounding tourism promotion in the Homelands began to occur from the 1960s. Following the 1963 grant of 'self-government' to Transkei there was recognition in South African parliamentary debates of the potential for developing tourism in the Transkei to glimpse 'Africa in the raw' and also of the corresponding need for improvement of the quality of local hotels in line with quality and grading standards which had been introduced in 1964-65 for South African hotels (Rogerson and Rogerson, 2022b). Attention was drawn to the increasing numbers of tour buses travelling into Transkei as well as tours that included overnight stops within Transkei. It was stated that "tours are arranged into the country districts, where dances are arranged for these overseas tourists to see. It is the most popular place for overseas tourists to-day" (House of Assembly Debates, 20 September 1966 Col. 3317). In particular, contrasts were drawn with Natal "where tours are not being arranged into Bantu areas any more, but in Transkei they are arranged for overseas visitors, and that is why the tours are so popular" (House of Assembly Debates, 20 September 1966 Col. 3317).

During the early 1970s, a period when the limitations and disappointments of planned industrial decentralisation programmes in the Bantustans, were becoming evident there were signs of further interest for promoting tourism in the Homelands. In parliamentary debates it was asserted that there might be "major advantages for the development of the tourism potential of the homelands" and that it was critically important "that the homelands be made aware of tourism, but particularly as far as the broad infrastructure of tourism is concerned" (House of Assembly Debates, 23 October, 1974 Col. 6210). Optimism was expressed for the development of tourism attractions in the Transkei "with its thrilling mountain scenery, trout fishing, sea angling along the Wild Coast, Coffee Bay and Mazeppa Bay" (House of Assembly Debates 23 October, 1974 Col. 6211). In 1974 South Africa's Minister of Tourism stated that "tourism is a very valuable asset" to the Homelands and in relative terms "it is of greater importance to them than to us" (House of Assembly Debates, 24 October, 1974 Col. 6255).

A major 'turning point' for tourism development was the acceptance of 'independence' by four of the Homelands. Notwithstanding widespread opposition towards the implementation of separate development, in 1976 Transkei became the first of South Africa's Bantustans to accept 'independence'. Wildman's (2005: 87) research at Coffee Bay shows that whilst 'independence' for Transkei 'may have created new forms of tourism opportunities for the black government, it at the same time upset the region's traditional tourist base". Coastal tourism proprietors reported occupancy rates dropped dramatically following 'independence' as the core base of regular white domestic tourists was nervous if not 'scared' of holidaying in an area with a black government. This said, the major factor behind the collapse of Wild Coast tourism in the late 1970 s was the decline of essential services. However, other tourism markets were opened by 'independence'. From the 1970s tourism became implicated in the apartheid project through the close linkages of major tourism enterprises and nontourism capital with the political leaders of the Homelands (Grundlingh, 2006; van Eeden, 2007). Tourism developers and Bantustan governments were facilitated to take advantage of the status of 'independence' as a means to circumvent South African government restrictions towards what was deemed as such 'morally dubious' activities such as gambling, interracial relations and pornography. The Transkei, as with other subsequent 'independent' Bantustans, "provided the ideal location for white South Africans to indulge themselves" (Wildman, 2005: 86).

The growth of casino tourism in the four independent Homelands is viewed by Briedenhann and Wickens (2004) as an early form of rural tourism in these areas. Timothy (2001) contends tourism developers and homeland governments used the independent status of homelands to circumvent the strict policies of the South African government and establish resort complexes as well as a network of large casinos. Rural tourism thus was boosted by the programme of casino developments in the Homelands. The Tswana homeland, Bophuthatswana, was the first to receive such casino developments. The imperative need of the apartheid state both to legitimise Bantustan independence and to wean these chronically impoverished areas from their revenue dependency upon South Africa produced what Crush and Wellings (1983) refer to as an alliance of convenience with tourism capital. In terms of the 1971 Self-Governing Territories Constitution Act the Bantustans were granted powers to write their own laws which allowed for the establishment of casinos alongside the legalisation of gambling. In addition there were other laws which sanctioned interracial relationships and pornography (van der Merwe, 2017).

All the Bantustans were non-viable economic entities, struggled to attain financial independence and survived only through massive subsidies provided by the (white) South African government. It is against such a backdrop that Lucas Mangope, Bophuthatswana's president, and the Southern Sun hotelier, Sol Kerzner, entered "a mutually beneficial relationship to create casinos within the borders of the bantustans" (van der Merwe, 2017: 2). Meetings between the two parties are known to have been taking place at least since 1976. The hotelier, Sol Kerzner, "utilised the political and moral landscape of apartheid South Africa, and drew on bantustan "independence" to establish several casinos in these apartheid-created rural spaces (van der Merwe, 2017: 14). After lengthy negotiations with the 'slumlords' of Bophuthatswana, Southern Sun concluded an agreement for exclusive gambling rights in the territory and began investing and promises to open the local tourism economy. The first hotel/casino complex in the Bantustans was built at Mmabatho, the capital of Bophuthatswana, and readied for its opening to coincide with 'independence' in December 1977. The Mmabatho casino was followed closely by the much larger and more ambitious Sun City complex, proclaimed to match Las Vegas, which opened during December 1979 (van Eeden, 2007).

The Sun City casino was located just two hours drive from South Africa's economic heartland and its major cities of Johannesburg and Pretoria. For the apartheid government Sun City was used "to legitimise the homelands and was a convenient tool to transfer the cost of subsidising the bantustans from state funds over to private investment" (van der 
Merwe, 2017: 21). In terms of the social production of space it was critical that Sun City was "literally established in another country" (van Eeden, 2007: 184). Sun City was designed in the lavish Las Vegas strip style, becoming the most notorious of all the Bantustan casinos with its roulette, slot machines, pornography, multi-racial sequined show revues and designer golf course. The establishment of "casinos and resorts in the bantustans satisfied the cravings of white South African for vices that they could not find at home" (van der Merwe, 2017: 1).

The casino rights to the 'independent' Homelands were divided between the two main hotel enterprises, the Holiday Inn and Southern Sun (Rogerson, 1990). The rights to casino development in Transkei and Venda were awarded to the South African subsidiary of Holiday Inn whilst Ciskei and Bophuthatswana granted the licence to Southern Sun. The period of the early 1980s was popularly styled as one of 'casino wars' which were played out between Southern Sun and Holiday Inn, as both enterprises sought to maximise access to the urban consumer gambling markets of South Africa by establishing competing casino resorts. Throughout the 1980s and early 1990s these mega-resort casino developments that were purposebuilt by Sun International within the Bantustans emerged as significant tourism nodes, especially for domestic South African tourism. Indeed, within only a few years of completion, Sun City was drawing over a million visitors per year, the majority day visitors, albeit with a growing segment qualifying as tourists by spending at least one night away from their normal place of residence (Rogerson, 2004). Nevertheless, in van der Merwe's (2017) detailed study of gambling in Bophuthatswana, it was demonstrated that whilst Sun City brought exposure and infrastructure to the area most of the justifications for casino development never materialised, including high tax revenues, increased local employment, and the development of a heritage for the Tswana people. Instead, it was concluded that the "Sun City casino scheme aimed to further enrich individuals such as Kerzner and Mangope with the promised benefits unrealised for the 'citizens' of Bophuthatswana. Similar conclusions are reached concerning the impacts of the casino development that occurred in Transkei (Wildman, 2005).

\section{CONCLUSION}

The historical evolution of rural tourism destinations is a knowledge gap in tourism and change literature surrounding the Global South. Using a range of archival sources this study provides a first glimpse of the tourism trajectories that emerged in South Africa's former 'Native Reserves' which formed the basis for the territories that under apartheid were called the Bantustans or Homelands. As described by one observer these areas constitute the "geographical scars of apartheid" (Jensen, 2015: 91). Arguably, the historical specificities of these rural spaces triggered the appearance of particular forms of rural tourism. Initially, in colonial times there occurred visits from small cohorts of international tourists who were in search of 'primitive Native life'. Under apartheid the group of 'independent' Homelands offered the ideal location for white South Africans to indulge themselves and "to participate in peccadilloes long denied to them at home" (Crush and Wellings, 1983: 683). Beyond gambling Haines and Tomaselli (1992: 156) highlight these areas functioned as "pockets of permissiveness" offering soft-porn movies, semi-nude cabaret and opportunities for inter-racial sexual liaisons which were banned elsewhere.

Although the Bantustans were abolished formally prior to democratic transition their geographies have left a lasting imprint in South Africa's rural areas (Ramutsindela, 2001; King and McCusker, 2007). Following democratic transition a new institutional environment emerged to impact leisure tourism possibilities in these areas. Changes in casino legislation eroded the comparative advantage of these rural spaces for gambling and forced the casino resorts to adapt their business strategy with re-adjustments of their product mix (Ezeuduji et al., 2014). Beyond the casinos the opportunities for growing cultural tourism became a new potential focus in many of the former rural Homeland spaces. Overall, however, in the postapartheid years these areas mostly have endured high levels of unemployment, becoming 'spaces of despair' and experiencing a situation of 'under-tourism' (Tseane-Gumbi and Ani, 2019). Schoeman (1998) showed that following democratic transition there had been virtually no tourism development in the former Qwa-Qwa Homeland. Likewise, it was disclosed after five years of post-apartheid national reintegration minimal tourist developments had taken place in the former Venda and Gazankulu Homelands (Anyumba, 2000). From 1994 most of the territory of the former Homelands became what has been styled as 'in-between' rural spaces and experienced minimal leisure tourism with local tourism dominated by visits from friends and relatives (Rogerson and Rogerson, 2021f). The unfolding of this 'modern' phase of rural tourism development in the former rural Homelands requires further exploration by tourism scholars.

\section{Acknowledgements}

Arabella Rogerson is thanked for editorial inputs and Wendy Job credited for preparation of the map. Robbie, Dawn and Skye Norfolk offered valued inputs. The University of Johannesburg provided research funding.

\section{REFERENCES}

Ally, S., \& Lissoni, A. (Eds.) (2017). New histories of South Africa's apartheid era Bantustans. London: Routledge.

Anyumba, G. (2000). Internet tourism networks and marketing: A case study of the potential and gaps in the former Homelands of the Northern Province in South Africa. Information Technology \& Tourism, 3 (1), 15-25.

Beinart, W. (2012). Beyond 'Homelands': Some ideas about the history of African rural areas in South Africa. South African Historical Journal, 64 (1), 5-21. https://doi.org/10.1080/02582473.2012.642225

Bickford-Smith, V. (2009). Creating a city of the tourist imagination: The case of Cape Town, 'The Fairest Cape of all'. Urban Studies, 46 (9), 1763-1785. https://doi.org/10.1177\%2F0042098009106013

Biko, S. (1987). I write what I like: A selection of his writings. Johannesburg: Heinemann.

Brett, M.R. (2018). Tourism in the Kruger National Park: Past development, present determinants and future constraints. African Journal of Hospitality Tourism and Leisure, 7 (2), 1-28. 
Briedenhann, J., \& Wickens, E. (2004). Rural tourism - Meeting the challenges of the new South Africa. International Journal of Tourism Research, 6 (3), 189-203. https://doi.org/10.1002/jtr.484

Bui, T.H. (2021). Tourism and colonization: Establishment of French Indochina Tourism in the early $20^{\text {th }}$ Century. Masters thesis, Ritsumeikan Asia Pacific University, Beppu, Japan.

Carlyle-Gall, C. (1937). Six thousand miles of sunshine travel over the South African Railways. Johannesburg: South African Railways and Harbours.

Carruthers, J. (1989). Creating a national park, 1910 to 1926. Journal of Southern African Studies, 15 (2), $188-216$. https://doi.org/10.1080/03057078908708197

Carruthers, J. (1995). The Kruger National Park: A social and political history. Pietermaritzburg: University of Natal Press.

Carruthers, J. (2013). The Royal Natal National Park, Kwazulu-Natal: Mountaineering, tourism and nature conservation in South Africa's first national park c.1896 to c.1947. Environment and History, 19, 459-485. https://doi.org/10.3197/096734013X13769033133701

Crush, J., \& Wellings, P. (1983). The Southern African pleasure periphery 1966-83. Journal of Modern African Studies, 21, 673-698. https://doi.org/10.1017/S0022278X00024265

Dlamini, J.S.T. (2020). Safari nation: A social history of the Kruger National Park. Athens, OH. USA: Ohio University Press.

Drummond, J., Drummond, F., \& Rogerson, C.M. (2021). Latent opportunities for heritage tourism in South Africa: Evidence from Mahikeng and surrounds. African Journal of Hospitality, Tourism and Leisure, 10 (5), 1591-1609. https://doi.org/10.46222/ajhtl.19770720-181

Evans, L. (2019). Contextualising apartheid at the end of empire: Repression, 'development' and the Bantustans. The Journal of Imperial and Commonwealth History, 47 (2), 372-411. https://doi.org/10.1080/03086534.2019.1605705

Ezeuduji, I., Lete, P.M., Correia, M., \& Taylor, A.M. (2014). Competitive advantage for brand positioning: The case of Sun City in South Africa. Tourism Review International, 17 (4), 299-306. https://doi.org/10.3727/154427214X13910101597283

Grundlingh, A. (2006). Revisiting the 'old' South Africa: Excursions into South Africa's tourism history under apartheid, 1948-1990. South African Historical Journal, 56, 103-122. https://doi.org/10.1080/02582470609464967

Haines, R.J., \& Tomaselli, K.G. (1992). Toward a political economy of the South African film industry in the 1980s. In C.R. Lehman \& R.M. Moore (Eds.), Multinational Culture: Social Impacts of a Global Economy,155-166, New York: Praeger.

Hanpachern, R., \& Chatkaewnapanon, Y. (2013). Understanding a tourism destination: A tourism history approach. International Journal of Asian Social Science, 3 (12), 2399-2408.

Hobart Houghton, D. (1957). The significance of the Tomlinson report. Africa South, 1 (2), 13-21.

Jensen, S. (2015). This house is not my own: Temporalities in a South African Homeland. Journal of Southern African Studies, 41 (5), 991-1004. https://doi.org/10.1080/03057070.2015.1068088

Jensen, S., \& Zenker, O. (2015). Homelands as frontiers: Apartheid's loose ends - an introduction. Journal of Southern African Studies, 41 (5), 937-952. https://doi.org/10.1080/03057070.2015.1068089

Jones, P.S. (1999). 'To come together for progress': Modernization and nation-building in South Africa's Bantustan periphery - the case of Bophuthatswana. Journal of Southern African Studies, 25 (4), 579-605. https://doi.org/10.1080/030570799108489

King, B.H. (2006). Placing Kangwane in South Africa. Geographical Review, 96 (1), 79-96. https://doi.org/10.1111/j.1931-0846.2006.tb00388.x

King, B.H., \& McCusker, B. (2007). Environment and development in the former Bantustans. The Geographical Journal, 173 (1), 6-12.

Lissoni, A., \& Ally, S. (2018). Bantustan states. African Historical Review, 50 (1-2), 1-3. https://doi.org/10.1080/17532523.2019.1596405

Mills, A.J., \& Mills, J.H. (2018). Archival research. In C. Cassell, A.L. Cunliffe \& G. Grandy (Eds.), The SAGE handbook of qualitative business and management research methods, London: SAGE.

Nieuwenhuysen, J.P. (1964). Economic policy in the reserves since the Tomlinson report. South African Journal of Economics, 32 (1), 3-25.

Norval, A.J. (1936). The tourist industry: A national and international survey. London: Sir Isaac Pitman.

Phillips, L. (2017). History of South Africa's Bantustans. In Oxford Research Encyclopaedia of African History. https://doi.org/10. 1093/acrefore/9780190277734.013.80

Pirie, G.H. (2022). Tourism histories in Africa. In E. Zuelow \& K. James (Eds.) Oxford handbook of tourism and travel history. New York: Oxford University Press.

Ramutsindela, M. (2001). The bitter harvest of the Bantustans. South African Geographical Journal, 83 (3), $175-182$. https://doi.org/10.1080/03736245.2001.9713734

Rassool, C., \& Witz, L. (1996). South Africa: A world in one country - moments in international tourist encounters with wildlife, the primitive and modern. Cahiers d'Études Africaines, 36 (143), 335-371.

Rogerson, C.M. (1990). Sun International: The making of a South African tourism multinational. GeoJournal, 22, 345-354. https://doi.org/10.1007/BF00192834

Rogerson, C.M. (2004). New directions for casino tourism in post-apartheid South Africa. In C.M. Rogerson \& G.Visser (Eds.), Tourism and development issues in contemporary South Africa, 161-181, Pretoria, Africa Institute of South Africa.

Rogerson, C.M. (2011). From liquor to leisure: The changing South African hotel industry 1928-1968. Urban Forum, 22 (4), $379-394$. https://doi.org/10.1007/s12132-011-9126-9

Rogerson, C.M. (2019). Business tourism under apartheid: The historical development of South Africa's conference industry. Urbani izziv, 30 (Supplement), 82-95.

Rogerson, C.M. (2020). Apartheid hotels: The rise and fall of the 'non-White' hotel in South Africa. In J. M. Rogerson \& G. Visser (Eds), New directions in South African tourism geographies, 33-54, Cham, Switzerland: Springer.

Rogerson, C.M., \& Baum, T. (2020). COVID-19 and African tourism research agendas. Development Southern Africa, 37 (5), $727-741$. https://doi.org/10.1080/0376835X.2020.1818551

Rogerson C.M., \& Rogerson, J.M. (2018). The evolution of hotels in Johannesburg 1890-1948: A case of historical urban tourism. GeoJournal of Tourism and Geosites, 23 (3), 738-747. https://doi.org/10.30892/gtg.23310-324

Rogerson, C.M., \& Rogerson, J.M. (2019). Historical urban tourism: Developmental challenges in Johannesburg 1920-1950. Urbani izziv, 30 (Supplement), 112-128.

Rogerson, C.M., \& Rogerson, J.M. (2020a). Resort development and pathways in South Africa: Hermanus, 1890-1994. In J. M. Rogerson \& G. Visser (Eds.), New directions in South African tourism geographies, 15-32, Cham, Switzerland: Springer.

Rogerson, C.M., \& Rogerson, J.M. (2020b). Racialized landscapes of tourism: From Jim Crow USA to apartheid South Africa. Bulletin of Geography: Socio-Economic Series, 48, 7-21. http://doi.org/10.2478/bog-2020-0010

Rogerson, C.M., \& Rogerson, J.M. (2021a). African tourism in uncertain times: COVID-19 research progress. GeoJournal of Tourism and Geosites, 38 (4), 1026-1032. https://doi.org/10.30892/gtg.38406-740

Rogerson, C.M., \& Rogerson, J.M. (2021b). Urban tourism under apartheid: The Johannesburg chapter. In C. M. Rogerson \& J. M. Rogerson (Eds), Urban tourism in the global south: South African perspectives, 149-172, Cham, Switzerland: Springer. 
Rogerson, C.M., \& Rogerson, J.M. (2021c). Climate therapy and the development of South Africa as a health resort, c1850-1910. Bulletin of Geography: Socio-Economic Series, 52, 111-121. https://doi.org/10.2478/bog-2021-0017

Rogerson, C.M., \& Rogerson, J.M. (2021d). Mundane urban tourism: The historical evolution of caravan parks in South Africa 19301994. In C.M. Rogerson \& J.M. Rogerson (Eds.), Urban tourism in the global South: South African perspectives, 93-112, Cham, Switzerland: Springer Nature.

Rogerson, C.M., \& Rogerson, J.M. (2021e). The evolution of rural tourism in South Africa: An historical lens. African Journal of Hospitality, Tourism and Leisure, 10 (6), 1728-1740. https://doi.org/10.46222/ajhtl.19770720-189

Rogerson, C.M., \& Rogerson, J.M. (2021f). 'In-between' rural tourism: Rethinking rural tourism spaces for policy development in South Africa. African Journal of Hospitality, Tourism and Leisure, 10 (4), 1394-1413. https://doi.org/10.46222/ajhtl.19770720-169

Rogerson, C.M., \& Rogerson, J.M. (2022a). The making of capital city tourism in South Africa. Tourism Review International, 26 (1).

Rogerson, C.M., \& Rogerson, J.M. (2022b). Historical turning points in tourism: The establishment of the Hotel Board in South Africa. Tourism Review International, 26 (1).

Rogerson, J.M. (2013). The changing accommodation landscape of Free State, 1936-2010: A case of tourism geography. African Journal for Physical, Health Education, Recreation and Dance, 18 (2 Supplement), 86-104.

Rogerson, J.M. (2017). Kicking sand in the face of apartheid: Segregated beaches in South Africa. Bulletin of Geography: SocioEconomic Series, 35, 93-109.

Rogerson, J.M. (2018). The early development of hotels in Johannesburg ca. 1928-1963. African Journal of Hospitality, Tourism and Leisure, 7 (4), 1-16.

Rogerson, J.M. (2019). The evolution of accommodation services in a coastal resort town: Hermanus, South Africa. African Journal of Hospitality, Tourism and Leisure, 8 (5), 1-16.

Rogerson, J.M. (2020). Johannesburg's iconic hotels: The life and death of the two Carltons. In J.M. Rogerson \& G. Visser (Eds.), New directions in South African tourism geographies, (pp. 55-74). Cham, Switzerland: Springer.

Rogerson, J.M., \& Visser, G. (2020). Recent trends in South African tourism geographies. In J.M. Rogerson \& G. Visser (Eds.), New directions in South African tourism geographies, (pp. 1-14). Cham, Switzerland: Springer.

Saarinen, J., Rogerson, C.M., \& Hall, C.M. (2017). Geographies of tourism development and planning. Tourism Geographies, 19 (3), 307-317. https://doi.org/10.1080/14616688.2017.1307442

Saarinen, J., \& Rogerson, J.M. (Eds.) (2021). Tourism, change and the Global South. Abingdon: Routledge.

Saunders, C., \& Barben, T. (2007). The history of tourism. In R. George (Ed), Managing tourism in South Africa, (pp. 25-31). Cape Town: Oxford University Press.

Schoeman, D.C. (1998). Identification of politico-geographic problems involved in establishing ecotourism in the former Homeland of Qwa-Qwa. MSc dissertation, Rand Afrikaans University, Johannesburg.

Schutte, G. (2003). Tourists and tribes in the 'new' South Africa. Ethnohistory, 50 (3), 473-487.

Sixaba, Z., \& Rogerson, C.M. (2019). Black economic empowerment and South African tourism: The early pioneers. African Journal of Hospitality, Tourism and Leisure, 8 (4), 1-10.

Smith, D.M. (2004). Social justice and the (South African) city: Retrospect and prospect. South African Geographical Journal, 86 (1), 1-6

Southall, R. (1982). Botha reformism, the Bantustan strategy and the marginalization of the South African periphery. Labour, Capital and Society, 15 (2), 6-39.

Timothy, D. (2001). Tourism and political boundaries. London: Routledge.

Tseane-Gumbi, L.A., \& Ani, K.J. (2019). Tourism and transformation in the South Africa's former Homelands: Lessons and implications for Africa. African Renaissance, Special Issue (September), 93-108.

Uys, C.J. (1936). Native life in South Africa: Introductory text and descriptive notes on the illustrations. Johannesburg: South African Railways and Harbours.

van der Merwe, N.S. (2017). Gambling in the Bophuthatswana Sun: Sun City and the political economy of a Bantustan casino: 19651994. MA Dissertation, University of the Witwatersrand, Johannesburg.

van Eeden, J. (2007). Gendered tourism space: A South African perspective. In A. Pritchard, N. Morgan, I. Ateljevic \& C. Harris (Eds.), Tourism and gender: Essays in embodiment, sensuality and experience, 182-206, Wallingford, CAB International, 182-206.

van Eeden, J. (2011). Surveying the 'empty land' in selected South African landscape postcards. International Journal of Tourism Research, 13, 600-612. https://doi.org/10.1002/jtr.832

Walton, J.K. (1997). Taking the history of tourism seriously. European History Quarterly, 27, 563-571.

Walton, J.K. (2005). Introduction. In J. K. Walton (Ed.). Histories of tourism: Representation, identity and conflict, 1-18. Clevedon: Channel View.

Walton, J.K. (2009a). Progress in tourism management: Prospects in tourism history: Evolution, state of play and future developments. Tourism Management, 30, 783-793. https://doi.org/10.1016/j.tourman.2009.05.010

Walton, J.K. (2009b). Histories of tourism. In T. Jamal \& M. Robinson (Eds.), The SAGE handbook of tourism studies, 115-129, London, SAGE.

Walton, J.K. (2009c). Welcome to the Journal of Tourism History. Journal of Tourism History, 1, 1-6. https://doi.org/10.1080/17551820902739034

Walton, J.K. (2011). Tourism and history. Oxford: Goodfellow Publishers.

Wildman, K. (2005). The beach: The making and remaking of Coffee-Bay (1945-2005). MPhil dissertation (Public Culture), Centre for African Studies, University of Cape Town, Cape Town.

Wolf, J.B. (1991). A grand tour: South Africa and American tourists between the wars. Journal of Popular Culture, 25, 99-116.

*** House of Assembly Debates, 19 February 1937, 20 September 1966, 30 September 1966, 23 October, 1974, 24 October, 1974.

*** South African Railways and Harbours (1926). South Africa: The sun country. Johannesburg: South African Railways and Harbours.

*** South African Railways and Harbours (1934). 5,000 miles through Southern Africa on the South African Railways. Johannesburg: South African Railways and Harbours.

*** South African Railways and Harbours (1939). Zululand. Johannesburg: South African Railways and Harbours.

*** South African Railways Tourist Office (1949). South African native studies. Johannesburg: South African Railways Tourist Office.

*** Union of South Africa (1955). Summary of the report of the commission for the socio-economic development of the Bantu Areas within South Africa. Pretoria: Government Printer, UG61/1955. Historical Papers, University of Witwatersrand, Johannesburg A1906.

*** United Nations Centre Against Apartheid (1970). "Native reserves" in South Africa. New York: United Nations Department of Political and Security Council Affairs, Notes and Documents. 